International Journal of Physical Sciences and Engineering
Available online at http://sciencescholar.us/journal/index.php/ijpse
Vol. 3 No. 1, April 2019, pages: $22 \sim 31$
e-ISSN : 2550-6943, p-ISSN : 2550-6951
https://doi.org/10.29332/ijpse.v3n1.246

\title{
Learning Models and Authentic Assessment on Football Skill Learning Achievement
}

$\underset{\text { CrossMark }}{\text { Cridtor updites }}$

\author{
I Wayan Artanayasa a, Made Kurnia Widiastuti Giri b
}

Article history: Received 27 August 2018, Accepted: 31 December 2018, Published: 15 March 2019

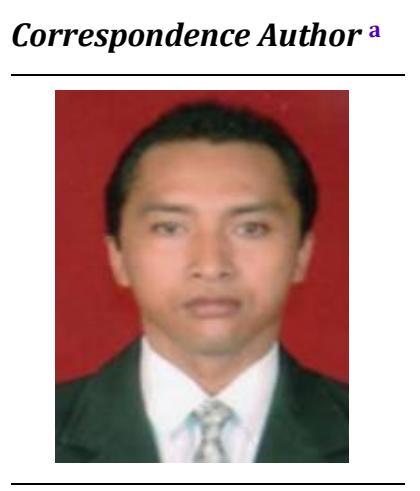

Keywords

authentic assessment; football skills; learning achievement; motor educability; teaching model;

\begin{abstract}
The current study was aimed at finding the effect of teaching models and an authentic assessment on football skill learning achievement by controlling motor educability. The sample consisted of 142 students of Physical Education Health Department that were selected randomly. The study used the $2 \times 2$ factorial experimental design, while the data were analyzed using 2-way ANACOVA. The results showed that after controlling motor educability, football skill learning achievement of the students who learned through the Cooperative Learning type Jigsaw model was higher than those who learned through the conventional model; the football skill learning achievement of those who were assessed by portfolio assessment was better than those who were assessed by authentic assessment. There was also an interaction between the teaching model and an authentic assessment on football skill learning achievement. The students who learned through the Cooperative Learning type jigsaw model was more appropriately assessed by portfolio assessment, while those who learned through the conventional learning model was more appropriately assessed by performance assessment. Based on the findings, it is suggested that to improve football skill learning achievement, the use of appropriate assessment as well as appropriate teaching model are needed
\end{abstract}

e-ISSN: 2550-6943, p-ISSN: 2550-6951 ๑ Copyright 2019. The Author. SS Journals Published by Universidad Técnica de Manabí. This is an open-access article under the CC BY-SA 4.0 license (https://creativecommons.org/licenses/by-sa/4.0/) All rights reserved.

\section{Contents}

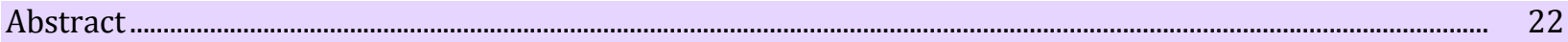

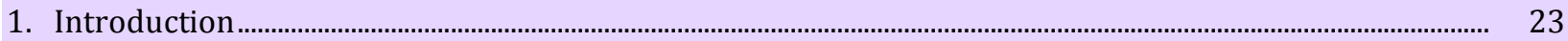

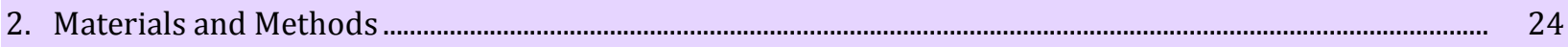

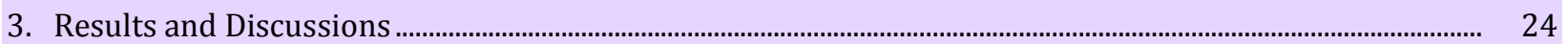

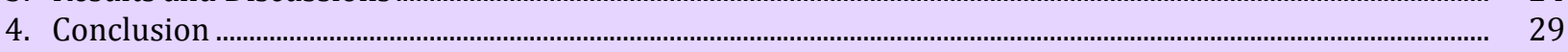

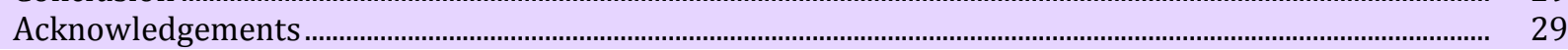

a Universitas Pendidikan Ganesha, Bali, Indonesia

b Universitas Pendidikan Ganesha, Bali, Indonesia 
References

\section{Introduction}

Both theoretical and practical courses of Football Learning have been compulsory skills subjects for students of the Physical Education Department at University. Through these courses, students are expected to have competencies related to physical education as early as possible, that is to understand and to master the various skills as well as knowledge about football as an integral part of educational competence. Based on the documentary research about football skills learning outcomes on the last 2 years (by 2012 and 2013 ), it is found that the achievement of university students' learning, especially on football skills, was very low. It can be seen from the scores gained. The majority of students achieved low scores, such as ' $\mathrm{B}$ ' and ' $\mathrm{C}$ ', while some others gained ' $D$ '. There were a small number of students who gained ' $A$ '.

Based on the results of observation and discussion with the researchers' colleagues, that is some lecturers who teach the courses, it is found that structured innovation in teaching-learning activity is required. Not only that, the structured innovation in organizing, presenting, and evaluating football skills courses are needed as well. Unexpected learning achievement is inseparable from the process of learning itself. One of the aspects that affect the learning process is the application of methods or models of learning activity. Suharta and Ardana (2006) defined the learning model as a conceptual framework that describes the systematic procedures in organizing the learning experience in order to achieve specific objectives as well as to serve as a guideline in planning and implementing learning. This indicates that the selection of the model of learning is very important to achieve learning objectives. A good learning model selection must be adjusted with the objectives of learning, the characteristics of the subject, and the characteristics of learners. Current research aims to compare the influence of conventional learning model and the influence of Cooperative Learning Type Jigsaw as the innovation of learning model. The conventional learning model is a model of learning which is designed to develop the learning of procedural knowledge. On the model, the lecturer plays important roles and is expected to be an interesting model for the student (Nur, 2011). According to Slavin (2009), learning model of Cooperative Learning Type Jigsaw is one of the most flexible cooperative models, since each member of the original group was given the material to be studied in expert groups. After that, they return to their original group to explain what they have learned. Through the model, students are taught not only to master knowledge but also to discuss and to be responsible for their group.

In another side, assessment is also important in the teaching-learning process. Through the assessment process, the educators will know how far students have mastered materials taught. The effectiveness of the learning model applied is related to the material presented. The skills learning achievement is dominant on the aspect of psychomotor because the assessment is focused more on the mastery of football skills. Counting those thoughts explained above, the assessment of football skills used authentic assessment. In the current research, the assessment is conducted on portfolio and performance assessment. Salvia \& Ysseldyke (1995) stated that portfolio assessment is a collection of learners' products, which used to demonstrate what they already have done. On the other sides, performance assessment is an assessment, in which the educators observe and give considerations about what students have known and done in their study (Norman, 1977).

In addition, learning a skill is influenced by a person's capacity and a duration of learning. Next, motor educability is a test that aims at predicting the learning potential and learning ability. It relates to the fastness or the slowness of someone in mastering a new skill (Kirkendall, 1987). A good relationship between the appropriate learning model and authentic assessments consideration will have an effect on the results of the learning skills, in this case, the skills of football. The current study examines 'the effect of learning model and an authentic assessment on learning football achievement by controlling motor educability'. In other words, it aims to know the effect of the learning model and the authentic assessment on learning football achievement by controlling motor educability.

Artanayasa, I., \& Giri, M. (2019). Learning models and authentic assessment on football skill learning achievement. International Journal of Physical Sciences and Engineering, 3(1), 22-31. https://doi.org/10.29332/ijpse.v3n1.246 


\section{Materials and Methods}

Method applied in current research was an experimental method. The dependent variable is the learning achievement of football skills, while the dependent variables are learning the model of Cooperative Learning Type Jigsaw, and authentic assessment that is portfolio and performance assessment. The co-variable is motor educability. Furthermore, this research applied design experiments of $2 \times 2$. According to Dantes (2010), the design is used to have some comparisons in one design, that is the main effect, the interaction effect, and the simple effect of independent variable towards dependent variable.

The population of the current research was all students of the Physical Education Department of Universitas Pendidikan Ganesha, academic year 2014/2015. A total number of students were 142 people. All of them were separated into four classes. The sample gained through random sampling techniques, by selecting randomly the four classes. Two classes were a sample of experimental groups, while two other classes were the sample of the control group. Through the technique, there were 100 students gained as samples. They were divided into four groups. Each group consisted of 25 students, with the details as follows: a) 25 students were given a model of Cooperative Learning Type Jigsaw and they were assessed by portfolio assessment, b) 25 people were given a model of Cooperative Learning Type Jigsaw, and they were assessed by performance assessment, c) 25 people were given a model of conventional learning and portfolio assessment, (d) 25 people were given a model of conventional learning and performance assessment.

In accordance with the design of the research, there two kinds of data i.e. data of the results in football learning skills, and data of motor educability of students. The instrument for gaining data is described as follows. The development phase of the instrument includes conceptual definition, the definition of the operational instruments, the test of data validity, and the reliability of the instrument.

Instruments were developed based on the theoretical review and the material of football skills learning. The dimension of the knowledge aspect of football consists of the history and development of soccer, soccer games, infrastructure, characteristics, the structure of the football game motion, and the basic techniques of soccer games. Aspects of the skill dimensions are passing, controlling technique, dribbling, and shooting. Test validity was conducted by examining content validity, that is through the validity of expert. The validity test was conducted in two stages, namely: (1) the validity of the panel, that is to review the accuracy of the instruments, and (2) the empirical validity. Next, the reliability coefficient of the instrument was analyzed using ANOVA Hoyt. Passing the process of validity, the data were stated as valid data to be used as a sample of research.

On the other side, data of motor educability were tested through IOWA Brace Motor Educability Test. This test consisted of 21 kinds, namely: 1) One foot-touch head, 2) Side leaning rest, 3) Gravine, 4) One knee balance, 5) Stork stand, 6) Double heel click, 7) Cross-leg squat, 8) Full left turn, 9) One knee-head to floor, 10) Hop backward, 11) Forward hand kick, 12) Full squat-arm circle, 13) Half-turn jump-left foot, 14) Three dips, 15) Sidekick, 16) Knee jump to foot, 17) Rusian dance, 18) Full right turn, 19) The top, 20) Single squat balance, and 21) Jump foot (Kirkendall, 1987).

Next, hypothesis examination was conducted using two lines ANACOVA. However, before presenting the quantitative analysis, the raw data were described in the form of a table, as well as in the visualization with graphic images of the histogram. After that, the test of normality was conducted. Data analysis was included a test of linearity and the test of regression co-variant motor educability (X) towards the results of the football skills learning $(\mathrm{Y})$, as well as the regression line alignment test. Following is the results of the examination and the discussion.

\section{Results and Discussions}

Data tabulation are grouped into eight groups, namely: 1) learning results of football skills and motor educability from students in model of Cooperative Learning Type Jigsaw (A1), 2) learning results of football skills and motor educability from students in the conventional learning model (A2), 3) learning results of football skills and motor educability from students that were given the portfolio assessment (B1), 4) learning results of football skills and motor educability from students that were given the performance assessment $(B 2), 5)$ learning results of football skills and motor educability from students who joined the Cooperative 
Learning Type Jigsaw, and were given an portfolio assessment (A1B1), 6) learning results of football skills and motor educability from students who joined the Cooperative Learning Type Jigsaw, and were given a performance assessment (A1B2), 7) learning results of football skills and motor educability from students who joined the conventional learning model, and were given portfolio assessment (A2B1), and 8) learning results of football skills and motor educability from students who joined the conventional learning model, and were given performance assessment (A2B2). The description of the data from the eight groups can be seen in the following table.

Table 1

Analysis results of football learning skills score

\begin{tabular}{|c|c|c|c|c|c|c|c|}
\hline \multirow{2}{*}{ BA } & & \multicolumn{2}{|c|}{$\mathrm{A}_{1}$} & \multicolumn{2}{|c|}{$\mathrm{A}_{2}$} & \multicolumn{2}{|c|}{ Total } \\
\hline & & $\mathrm{X}$ & Y & $X$ & Y & $\mathrm{X}$ & Y \\
\hline \multirow{6}{*}{$\mathrm{B}_{1}$} & $\mathrm{~N}$ & 25 & 25 & 25 & 25 & 50 & 50 \\
\hline & Total & 763 & 1546 & 657 & 1061 & 1420 & 2607 \\
\hline & Mean & 30.5 & 61.8 & 26.3 & 42.4 & 28.4 & 52.1 \\
\hline & $\mathrm{s}^{2}$ & 20.0 & 97.9 & 16.4 & 51.0 & 22.4 & 168.9 \\
\hline & Max & 39 & 84 & 36 & 56 & 39 & 84 \\
\hline & Min & 24 & 44 & 22 & 30 & 22 & 30 \\
\hline \multirow{6}{*}{$\mathrm{B}_{2}$} & $\mathrm{~N}$ & 25 & 25 & 25 & 25 & 50 & 50 \\
\hline & Total & 676 & 1075 & 682 & 1281 & 1358 & 2356 \\
\hline & Mean & 27.0 & 43.0 & 27.3 & 51.2 & 27.2 & 47.1 \\
\hline & $\mathrm{s}^{2}$ & 15.4 & 48.3 & 19.2 & 113.9 & 17.0 & 96.8 \\
\hline & Max & 36 & 58 & 35 & 78 & 36 & 78 \\
\hline & Min & 22 & 32 & 22 & 32 & 22 & 32 \\
\hline \multirow{6}{*}{ Total } & $\mathrm{N}$ & 50 & 50 & 50 & 50 & 100 & 100 \\
\hline & Total & 1439 & 2621 & 1339 & 2342 & 2778 & 4963 \\
\hline & Mean & 28.8 & 52.4 & 26.8 & 46.8 & 27.8 & 49.6 \\
\hline & $\mathrm{s}^{2}$ & 20.4 & 162.2 & 17.7 & 100.5 & 19.9 & 137.9 \\
\hline & Max & 39 & 84 & 36 & 78 & 39 & 84 \\
\hline & Min & 22 & 32 & 22 & 30 & 22 & 30 \\
\hline
\end{tabular}

There is a difference between the learning results of the students who joined the Cooperative Learning Type Jigsaw model and the students who joined the conventional learning model, after controlling motor educability. The average scores of students who joined Cooperative Learning Type Jigsaw model are 52.14, while the average score of students who joined the conventional learning model is 46.51(on the F Examination, the value of $\mathrm{F}$ - Count $=4.267$. It is higher than the value of $\mathrm{F}_{\text {table, }}$, which is only 3.941).

There is also a difference between the learning results of the students who were given the portfolio assessment and the students who were given conventional, after controlling motor educability. $\mathrm{F}_{\text {count }}=5.954$ is

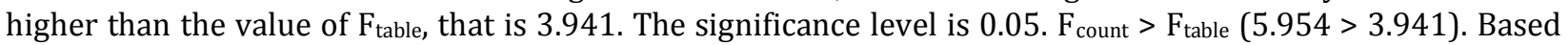
on the results of the third hypothesis examination, it is showed that the value of statistical F- test is 58.992, while the value of $F_{\text {table }}$ is 3.941. In other words, F-test is higher than $F_{c}$. The significance level is $\alpha=0.05$. That means $\mathrm{H}_{0}$ is rejected. The rejection draws a statement that there was an influence between authentic assessments towards learning results of football skills, after controlling motor educability. Next, further examination of the hypothesis (post hoc) was conducted.

The result of the further examination showed that the value of statistical t-lines test $[(A=1) *(B=1)]$ obtained a value of $t_{\text {count }}=6.702$ higher than the value of $t_{\text {table, }}$, that is 1.985. The significance level $\alpha=0.05$. This means $t_{\text {count }}>t_{\text {table }}(6,702>1.985)$. Therefore $H_{0}$ is rejected, which means that for students who were given portfolio assessment, there are differences between those who joined Cooperative Learning Type Jigsaw model and those who joined conventional learning model, after controlling motor educability. Furthermore, it can also be seen in the averages values of students who were given a portfolio assessment. The results of the football learning skills of those who joined the model of Cooperative Learning Type Jigsaw is 61.73, while those who joined the conventional learning model have got only 42.27. Based on the fact, It can be concluded Artanayasa, I., \& Giri, M. (2019). Learning models and authentic assessment on football skill learning achievement. 
that for students who have got portfolio assessment, those who joined model of Cooperative Learning Type Jigsaw has got higher assessment than those who joined the conventional learning model.

Based on the result of the hypothesis examination, it can be seen that the value of $\mathrm{t}$-lines test statistic [( $\mathrm{A}=$ $1) *(B=2)]$ has obtained $t_{\text {count }}=4.124$. It is higher than the value of $t_{\text {table, }}$ which is only $1.985(4.124>1.985)$. The significance level $\alpha=0.05$. $\mathrm{H}_{0}$ is rejected, which means that for a group of students who were given performance assessment, there is a difference between those who joined model of cooperative learning type jigsaw and those who joined conventional learning model. Further, it can be seen through the average scores of groups. On the group of students who have got performance assessment, those who joined the Cooperative Learning Type Jigsaw model have got 48.12 while those who joined the conventional learning model, have got 51.06.

Next, on the group of students who joined the cooperative learning model of type jigsaw, there is a difference achievement between those who were given portfolio assessment and those who were given performance assessment, after controlling the motor educability. The average value shows that for the students who joined the model of cooperative learning type jigsaw, those who were given portfolio assessment have got a higher score than those who have got performance assessment, after controlling motor educability (test-t line $[(A=1) *(B=1)]$ has got $t_{\text {count }}=7.065$ more than $t_{\text {table }} 1.985$; that is $\left.7.065>1.985\right)$.

For students who joined conventional learning model, there are differences on their football learning skills achievement, that is between those who were given portfolio assessment and those who were given the performance assessment, after controlling the motor educability. Furthermore, based on the results, the achievement of students who were given the portfolio assessment $\left(t_{\text {table }}\right)$ is lower than students who were given performance assessment $\left(t_{\text {count }}\right)\left(t\right.$ line- test $[(A=2) *(B=1)]$ has obtained $t_{\text {count }}$ value $=3.207$, which is higher than ttable $=1.988$ ).

The result of first hypothesis examination has shown that the football skills learning achievement, which joined learning model of Cooperative Learning Type Jigsaw, is higher than the result of conventional learning model, after controlling motor educability. The results of these analyses are in accordance with the theories that have been described before, that is, learning model of Cooperative Learning Type Jigsaw is a learning strategy in which heterogeneous small groups can exchange responsibility in studying. This learning model encourages students to be active for helping each other, especially in mastering the material of course given. This is emphasized by Slavin (1995). He stated that the model of Cooperative Learning Type Jigsaw is one of the most flexible models because each of the students was given a material to be discussed in an origin group. The technique splits classes into mixed groups to work on small problems that the group collates into a final outcome. For example, an in-class assignment is divided into topics.

Students are split into groups with one member assigned to each topic. Working individually, each student learns about his or her topic and presents it to their group. Next, students gather into groups divided by topic. Each member presents again to the topic group. In same-topic groups, students reconcile points of view and synthesize information. They create a final report. Finally, the original groups reconvene and listen to presentations from each member. The final presentations provide all group members with an understanding of their own material, as well as the findings that have emerged from the topic-specific group discussion. This indicates that the Group's success depends on the success of a member. Therefore, in the learning process, students with more capabilities will be tutor their friends. Through this learning model, students will become more active and can develop the ability to think and to learn more since the students will try their best to find the concept, or the football skills movement. While conventional learning is just traditional customary learning, which is usually delivered by lecturers in the classroom or out of the classroom. According to Busching and Lundsteen, conventional learning is an old model of learning (in Ratu Irma, 2010). The conventional learning model is traditional teacher-centered methods focused on rote learning and memorization. The students will be passive because they just do what is instructed by lecturers. In football skills learning, it will not develop students' ability to conducting football movement skills.

Based on the result of the second hypothesis examination, it is found that the achievement of students who were given portfolio assessment is higher than students who were given performance assessment, after controlling motor educability. The statement above is supported by the result of a theoretical study about portfolio assessment. According to Salvia and Ysseldyke, portfolio is a compilation of academic work and other forms of educational evidence assembled for the purpose of (1) evaluating coursework quality, learning progress, and academic achievement; (2) determining whether students have met learning standards or other 
academic requirements for courses (Salvia \& Ysseldyke, 1995). While Butler \& McMunn (2006), state that portfolio is defined as a goal, an integrated collection of the work of learners who show effort, progress, or skill level. Thus, the more portfolio tasks are given for students, the more creative and trained they are. Portfolio assessment focus on the process and outcomes of learning. While performance assessment is only focused on students' performance, that is to know students' knowledge. It is emphasized more on performance assessment without compromising results.

The result of the analysis has shown that there was an interaction between the models of learning and the authentic assessment towards the achievement of football skills learning. Hypothesis examination is supported by the theory, that is, in the process of learning, there are two important things that should be considered. First, materials provided to learners should be delivered in creative ways, such as by using creative and innovative model. The second is an assessment that is applied. It must also be adapted to the learning objectives. One assessment that can be applied is an authentic assessment. Educators use the term authentic assessment to define the practice of realistic student involvement in the evaluation of their own achievements. Authentic assessments are performance-based, realistic, and instructional appropriate (Pett, j. 1990). The statement is emphasized by Grace (1990). She stated that an authentic assignment is one that requires the application of what students have learned to a new situation, and that demands judgment to determine what information and skills are relevant and how they should be used. Authentic assignments often focus on messy, complex real-world situations.

The application of appropriate learning model, which supported with a proper assessment, will generate good learning results. The impact of the interaction between the learning model and authentic assessment can be examined through the difference of results in football skills learning. Football skills learning achievement depends on the interaction between the learning model and authentic assessment. Model of Cooperative Learning Type Jigsaw has got a better impact on the achievement of football skills learning when the portfolio assessment is applied. While the students who are taught using the conventional learning model will have better achievement when the performance assessment is applied. Based on the hypothesis examination, and the discussion above, it can be included that football skills learning will be effective, as well as optimal, when the authentic assessment is given is in accordance with the custom of the learning process.

Research hypothesis which states that the group of students who have got portfolio assessment, the achievement of those who joined cooperative learning model of type jigsaw is higher than the achievement of students who joined the conventional model (after controlling motor educability), has been examined empirically, and reinforced with the acquisition of statistical scores on the current research. This finding can be explained based on the theoretical review, that is, learning model of cooperative type jigsaw can train students in solving problems as well as to make students be responsible for the tasks given (Johnson, 1984). Groups of students that were given a learning model of cooperative type jigsaw are suitable to be given the portfolio assessment since the portfolio shows the efforts, achievements, and developments of students (Kunandar, 2013). Through the learning model of Cooperative Learning Jigsaw Type students are able to cooperate and work together to make connections between their knowledge and their application in daily life, involving the seven main components of learning, namely constructivism (questioning), inquiry, learning community, modeling, reflection, and authentic assessment. Portfolio assessment examined the process. Hypothesis examination that is about student performance assessment, in the relationship with learning model, is acceptable.

The examination is in accordance with the theoretical review, that is, the activity of students who were given performance assessment is more on listening explanation about performance. Kunandar (2013), stated that performance assessment is an assessment which asks students to demonstrate and to apply knowledge in the appropriate context that has been determined. It is accordingly to what Gronlund stated. He stated that the task of performance focuses on poses, product, or a combination of both (Gronlund, 1977). Students in this group are more comfortable to be given explanations and examples of the movement model that is discussed in the material. They have no active interaction between students and lecturers. The students' custom, that is passive and less interaction is in accordance with the conventional learning model. They are more suitable to be given a performance assessment.

On the treatment, students in the group will be more able to acting skill without changing their habit. Next, based on the theoretical review as well as the result of the current study, a conclusion can be drawn as follow. For the group of students who were given performance assessment, the achievement of those who joined the

Artanayasa, I., \& Giri, M. (2019). Learning models and authentic assessment on football skill learning achievement. International Journal of Physical Sciences and Engineering, 3(1), 22-31. https://doi.org/10.29332/ijpse.v3n1.246 
learning model of Cooperative Learning Type Jigsaw is lower than those who joined the conventional learning model.

The research hypothesis stated that for the group of students who joined learning model of Cooperative Learning Type Jigsaw, those who are given portfolio assessment, have got higher achievement than those who were given performance assessment, after controlling motor educability. Based on the study of the theory, that explained about learning model of Cooperative Learning Type Jigsaw, it is stated that the type of learning helps students in developing understanding and their attitude, in accordance with their real life/ community. By working collectively among fellow members of the group, motivation, productivity and study achievement will be increased.

According to Slavin (1995), a model of cooperative learning, Jigsaw-type is one of the most flexible cooperative models, because each student was given material, and then be shared as well as discussed in Group. The technique splits classes into mixed groups to work on small problems that the group collates into a final outcome. For example, an in-class assignment is divided into topics. Students are then split into groups with one member assigned to each topic. Working individually, each student learns about his or her topic and presents it to their group. Next, students gather into groups divided by topic. Each member presents again to the topic group. In same-topic groups, students reconcile points of view and synthesize information. They create a final report. Finally, the original groups reconvene and listen to presentations from each member. The final presentations provide all group members with an understanding of their own material, as well as the findings that have emerged from the topic-specific group discussion.

The portfolio assessment is a means of providing an alternate assessment and provides benefits to both students and lecturers as an instructional method. It allows students to earn credit for the process of learning rather than for performance on a test. The process of assembling a portfolio can also increase communication among students. Butler \& McMunn (2006), defined a portfolio as a goal, an integrated collection of the work of learners, that shows effort, progress, or skill level. Cooperative Learning Type Jigsaw model pushes students to be active in understanding or mastering the material being taught. This is in accordance with the assessment of assessing activity undertaken by the students because the portfolio assessment itself is a procedure of collecting information about the development and capabilities of the students. For the group of students who joined the model of Cooperative Learning Type Jigsaw, the result for those who have got portfolio assessment are higher than those who have got performance assessment, after controlling motor educability.

The result of hypothesis examination has proved that for the group of students who joined the conventional learning model, those who were given portfolio assessment have got lower scores than those who were given performance assessment. Based on the findings, it is stated that those who join the conventional learning model, the suitable assessment is a performance assessment. On the other words, portfolio assessment is not suitable for conventional learning model, in this case, for football skills learning. Based on the theoretical study about the conventional learning model, as has been stated above, it is a model of teacher-centered learning. Successful of students depends on how lecturers deliver the material. Through the conventional learning model, students become accustomed to accepting what is given by the lecturer without pushing themselves to have more knowledge/skills by themselves. This type fits to be given a performance assessment.

Nitko (2001), defines performance assessment as a procedure for giving task for students. Performance assessment is seen as a better possibility to measure complex skills and communication. This indicates that the performance assessment demands students to show their performance as the reflection of their knowledge. This assessment requires students to apply the knowledge and skills to demonstrate that they have mastered the learning targets. Performance assessment is the assessment in which the teacher observes and makes considerations about what students have known and what they can do in their studies. Based on hypothesis examination, as well as the theoretical review and the result of the current study, it is stated that for the group of students who joined conventional learning model, those who were given portfolio assessment have got lower achievement than those who were given performance assessment, after controlling motor educability. 


\section{Conclusion}

Based on data obtained, and the analysis, as well as the hypothesis examination, it can be inferred several points as follows. 1) Football skills learning achievement of students who have joined model of Cooperative Learning Type Jigsaw is higher than the students who have joined the conventional learning after controlling motor educability; 2) Football skills learning achievement of students who were given portfolio assessment is higher than those who were given performance assessment after controlling motor educability; 3) There is the influence between the learning model with authentic assessment towards the results of football skills learning after controlling motor educability; 4) For the groups of students who were given portfolio assessment, those who joined the model of Cooperative Learning Type Jigsaw, have got higher achievement than those who joined the conventional learning model after control motor educability; 5) For the groups of students who were given performance assessment, those who joined cooperative learning model type jigsaw have got lower achievement than those who joined the conventional learning model, after controls motor educability; 6) For the groups of students who joined the model of cooperative learning type jigsaw, those who were given portfolio assessment have got higher achievement than those who were given conventional assessment; and 7) For the groups of students who joined the conventional learning models, those who were given portfolio assessment have got lower achievement than those who were given performance assessment, after controlling the motor educability.

\section{Acknowledgments}

This is self-supported research.

Artanayasa, I., \& Giri, M. (2019). Learning models and authentic assessment on football skill learning achievement. International Journal of Physical Sciences and Engineering, 3(1), 22-31. 


\section{References}

Baumgartner, T. A., \& Jackson, A. S. (1998). Measurement for evaluation in physical education and exercise science (No. Ed. 6). WCB/McGraw-Hill. https://www.cabdirect.org/cabdirect/abstract/19991800395

Butler, S. M., \& McMunn, N. D. (2006). A Teacher's Guide to Classroom Assessment: Understanding and Using Assessment to Improve Student Learning. Jossey-Bass, An Imprint of Wiley. 10475 Crosspoint Blvd, Indianapolis, IN 46256. https://eric.ed.gov/?id=ED493644

Danielson, C., \& Dragoon, J. (2013). A Collection of Performance Tasks \& Rubrics: Upper Elementary Mathematics. Routledge. https://content.taylorfrancis.com/books/download?dac=C2013-0-206899\&isbn=9781317920847\&format=googlePreviewPdf

Dantes, N. (2012). Metode Penelitian, Yogyakarta; CV. Andi Offset.

Elliott, S. N. (1994). Creating Meaningful Performance Assessments: Fundamental Concepts. Performance Assessment: CEC Mini-Library. Council for Exceptional Children, 1920 Association Dr., Reston, VA 220911589. https://eric.ed.gov/?id=ED375566

Grace, J. K., Yates III, J. R., \& Tome, C. I. M. (1996). Termite-resistant construction: use of a stainless steel mesh $\begin{array}{llll}\text { to } & \text { exclude } & \text { Coptotermes } & \text { 365-372. }\end{array}$ https://www.ctahr.hawaii.edu/gracek/pdfs/110.pdf

Gronlund, N. E. (1982). Constructing achievement tests. Prentice Hall.

Johnson, D. W., Johnson, R. T., \& Stanne, M. B. (2000). Cooperative learning methods: A meta-analysis. http://www.academia.edu/download/33787421/Cooperative_Learning_Methods_A_Meta-Analysis.pdf

Kirkendall, D. R., Gruber, J. J., \& Johnson, R. E. (1987). Measurement and evaluation for physical educators.

Kunandar, D. (2013). Penilaian Autentik (Penilaian Hasil Belajar Peserta Didik Berdasarkan Kurikulum 2013).

Lerner, J. W. (1976). Children with learning disabilities: theories, diagnosis, teaching strategies. Houghton Mifflin School.

Marhaeni, A. A. I. N. (2004). Portofolio Dalam Pembelajaran Suatu Pendekatan Asesmen Berbasis Kompetensi. Makalah. Singaraja: IKIP Negeri Singaraja.

Mielke, D. (2007). Dasar-dasar sepak bola. Bandung: Pakar Raya.

Nitko, A. J. (2001). Conceptual Frameworks to Accommodate the Validation of Rapidly Changing Requirements $\begin{array}{llll}\text { for } \quad \text { Assessments. Curriculum assessment, } & 143 .\end{array}$ http://repository.stkipgetsempena.ac.id/bitstream/565/1/Curriculum_and_Assessment.pdf\#page=151

Nur, M. (2011). Model Pengajaran Langsung. Surabaya: Pusat Sains dan Matematika Sekolah Unesa.

Pett, J. (1990). What is authentic evaluation? Common questions and answers. FairTest Examiner, 4, 8-9.

Putri, R., \& Indra, I. (2010). Pengaruh pendekatan pembelajaran dan bentuk tes formatif terhadap hasil belajar matematika dengan mengontrol intelegensi siswa sd di Palembang [The effect of learning approach dan formative test to mathematic learning outcome: Study in Palembang public elementary student](Postgraduate dissertation, Jakarta State University, Indonesia) (Doctoral dissertation, Tesis Universitas Negeri Jakarta).

Slavin, R. E. (1995). Cooperative Learning: Theory. Research and Practice.(2nd ed.) Boston: Allyn \& Bacon.

Slavin, R. E. (2009). Cooperative learning: teori, riset, dan praktik.(terjemahan Lita). Bandung: Nusa Media.

Sucipto, Bambang Sutiyono, Indra, M. Thohir, and Nuryadi. (2000) Sepakbola Jakarta: Departemen Pendidikan dan Kebudayaan.

Sudjana, N. (1999). Nana, Penilaian Hasil Belajar Mengajar.

Suharta, G. \& Ardana, M. (2006) “Jenis-Jenis Model Pembelajaran," Paper presented in Penataran Dosen Muda Pola 90 Jam, Singaraja, 3 September 2006. 


\section{Biography of Authors}

\begin{tabular}{|l|l|}
\hline I Wayan Artanayasa is a Doctor of Physical Education and Sports Sciences. He is a \\
lecturer as well as a senior researcher at Universitas Pendidikan Ganesha, \\
Indonesia. Currently, he is interested in Sports assessment and measurement, \\
physical education, and sports sciences. \\
Email: wayan.artanayasa@undiksha.ac.id
\end{tabular}

Artanayasa, I., \& Giri, M. (2019). Learning models and authentic assessment on football skill learning achievement. International Journal of Physical Sciences and Engineering, 3(1), 22-31. https://doi.org/10.29332/ijpse.v3n1.246 